Members. The 17 fully participating National Central Banks are from: Austria, Belgium, Cyprus, Estonia, Finland, France, Germany, Greece, Ireland, Italy, Luxembourg, Malta, Netherlands, Portugal, Slovakia, Slovenia and Spain. The other ten EU members (those which do not use the euro as their currency) have special status.

Functions. The primary objective of the ESCB is to maintain price stability. Without prejudice to this, the ESCB supports general economic policies in the Community with a view to contributing to the achievement of the objectives of the Community. Tasks to be carried out include: i) defining and implementing the monetary policy of the Community; ii) conducting foreign exchange operations; iii) holding and managing the official foreign reserves of the participating member states; iv) promoting the smooth operation of payment systems; v) supporting the policies of the competent authorities relating to the prudential supervision of credit institutions and the stability of the financial system.

The ECB has the exclusive right to issue banknotes within the Community.

Organization. The ESCB is governed by the decision-making bodies of the ECB: the 23-member Governing Council and the Executive Board. The Governing Council is the supreme decisionmaking body and comprises all members of the Executive Board plus the governors of the NCBs forming the Eurosystem. The Executive Board comprises the president, vice-president and four other members, appointed by common accord of the heads of state and government of the participating member states. There is also a General Council which will exist while there remain members with special status.

Address: Kaiserstrasse 29, 60311 Frankfurt am Main, Germany. Website: http://www.ecb.int

President: Mario Draghi (Italy).

\section{Other EU Structures}

\section{European Investment Bank (EIB)}

The EIB is the financing institution of the European Union, created by the Treaty of Rome in 1958 as an autonomous body set up to finance capital investment furthering European integration. To this end, the Bank raises its resources on the world's capital markets where it mobilizes significant volumes of funds on favourable terms. It directs these funds towards capital projects promoting EU economic policies. Outside the Union the EIB implements the financial components of agreements concluded under European Union development aid and co-operation policies. The members of the EIB are the member states of the European Union, who have all subscribed to the Bank's capital. Its governing body is its Board of Governors consisting of the ministers designated by each of the member states, usually the finance ministers.

Address: 98-100 Blvd Konrad Adenauer, L-2950 Luxembourg. Website: http://www.eib.org

President and Chairman of the Board: Werner Hoyer (Germany).

European Investment Fund Founded in 1994 as a subsidiary of the European Investment Bank and the European Union's specialized financial institution. It has a dual mission that combines the pursuit of objectives such as innovation, the creation of employment and regional development with maintaining a commercial approach to investments. It particularly provides venture capital and guarantee instruments for the growth of small and medium-sized enterprises (SMEs). In 2002 it began advising entities in the setting up of financial enterprise and venture capital and SME guarantee schemes. A team has been created to structure and expand its advisory services.

Address: 96 Blvd Konrad Adenauer, L-2968 Luxembourg.

\section{European Data Protection Supervisor}

The European Data Protection Supervisor protects those individuals whose data are processed by the EU institutions and bodies by advising on new legislation and implications, processing and investigating complaints, and promoting a 'data protection culture' and awareness. The present incumbent is Peter Hustinx (Netherlands).

Address: Rue Wiertz, 60-MO 63, B-1047 Brussels, Belgium.

Website: http://www.edps.europa.eu

Email: edps@edps.europa.eu

\section{European Ombudsman}

The Ombudsman was inaugurated in 1995 and deals with complaints from citizens, companies and organizations concerning maladministration in the activities of the institutions and bodies of the European Union. The present incumbent is P. Nikiforos Diamandouros (Greece).

\section{Address: 1 avenue du Président Robert Schuman, CS 30403 F-67001 Strasbourg Cedex, France. \\ Website: http://www.ombudsman.europa.eu}

Advisory Bodies There are two main consultative committees whose members are appointed in a personal capacity and are not bound by any mandatory instruction.

1. European Economic and Social Committee. The 344-member committee is consulted by the Council of Ministers or by the European Commission, particularly with regard to agriculture, free movement of workers, harmonization of laws and transport. It is served by a permanent and independent General Secretariat, headed by a Secretary-General.

\section{Secretary-General: Martin Westlake (UK).}

2. Committee of the Regions. A political assembly which provides representatives of local, regional and city authorities with a voice at the heart of the European Union. Established by the Maastricht Treaty, the Committee consists of 344 full members and an equal number of alternates appointed for a four-year term. It must be consulted by the European Commission and Council of Ministers whenever legislative proposals are made in areas which have repercussions at the regional or local level. The Committee can also draw up opinions on its own initiative, which enables it to put issues on the EU agenda.

President: Mercedes Bresso (Italy).

\section{Main EU Agencies}

\section{Policy Agencies}

Agency for the Cooperation of Energy Regulators Launched in 2011 to assist and coordinate the work of national regulatory authorities, ensuring the proper functioning of the single European market in gas and electricity.

Address: Trg republike 3, 1000 Ljubljana, Slovenia.

Website: http://www.acer.europa.eu 